\title{
A Survey of Ectoparasites of Wild Bird Species at Two Gallery Forests Along River Benue at Makurdi Benue State, Nigeria
}

\author{
Stephanie Mdzuami Adelusi ${ }^{1,}$, , Isegbe Emmanuel Onah ${ }^{2}$, Edward Agbo Omudu $^{1}$ \\ ${ }^{1}$ Department of Biological Sciences, Benue State University, Makurdi, Nigeria \\ ${ }^{2}$ Federal College of Veterinary and Medical Laboratory Technology, National Veterinary Research Institute, Vom-Jos, Nigeria \\ Email address: \\ astephanie@bsum.edu.ng (S. M. Adelusi), isegbeonah@gmail.com (I. E. Onah), eddieomudu@yahoo.com (E. A. Omudu) \\ ${ }^{*}$ Corresponding author
}

\section{To cite this article:}

Stephanie Mdzuami Adelusi, Isegbe Emmanuel Onah, Edward Agbo Omudu. A Survey of Ectoparasites of Wild Bird Species at Two Gallery Forests Along River Benue at Makurdi Benue State, Nigeria. American Journal of Entomology. Vol. 2, No. 2, 2018, pp. 10-15.

doi: $10.11648 /$ j.aje.20180202.12

Received: June 14, 2018; Accepted: June 28, 2018; Published: July 24, 2018

\begin{abstract}
A survey of ectoparasite species infesting wild birds at two gallery forests in Makurdi was investigated to provide baseline information on the types of ectoparasites infesting wild birds. Birds were trapped from September 2015 to August 2016; a combination of visual examination and dust ruffling technique was used to remove ectoparasites from live birds. Specimens were preserved in labeled vials containing 70\% alcohol. The parasites were identified using standard taxonomic keys when viewed under a light microscope. A total of 254 birds were captured out of which, $174(68.5 \%)$ were infested with 1,294 ectoparasites (1,208 lice, 25ticks, 50 mites and 11 flies). The birds had high single infestation 107(42.1\%). Ectoparasitic infestation varied significantly between months $\left(\mathrm{F}_{(11,253)}=2.620, \mathrm{P}<0.05\right)$ and between bird species $\left(\mathrm{F}_{(58,253)}=2.353, \mathrm{P}<0.05\right)$, with the months of May and June showing higher infestations and at the Mu gallery Forest. The study concludes that there is high prevalence of ectoparasites on wild birds at gallery forests hence making the forests possible reservoir for ectoparasites for domestic birds. The study recommends further studies to determine the effects of parasites on the health of wild birds and possible transmission of parasites from wild to domestic birds.
\end{abstract}

Keywords: Disease, Host, Infestation, Lice, Prevalence, Vectors

\section{Introduction}

Ectoparasites are a diverse group of organisms that inhabit the integument of its host and feed on dead skin cells, tissues, fluids, blood and lymph [1]. When in large aggregation they may debilitate animals in other ways by causing various disorders such as anemia, detrimental immune reactions (hypersensitivity), skin necrosis, low weight gains, blockage of orifices and secondary infections [2-4].

In Birds, ectoparasites are known to cause selection pressures on host population, by lowering nestling survival and growth [5, 6], influencing the evolution of bird coloration [7], increasing the cost of sexual ornamentation [8], lowering of mating success and reduce fecundity [4]. As members of the ecosystems, birds play many important roles, including as predators, pollinators, scavengers, seed dispersers, seed predators, and ecosystem engineers $[9,10]$, which sustain the ecosystem both directly and indirectly.

In Nigeria, there are about 940 species of wild birds of which four are endemic and five are accidental or rare[11]. Some of these birds are also migrants which use Nigeria as their wintering grounds. Unfortunately, there are a number of factors that pose as threats to the avifauna of Nigeria amongst which include parasitism and diseases [12].

Most ectoparasites are disease vectors, for instance the fowl tick, a soft-bodied tick of the family Argasidae, is the most important poultry ectoparasite in many countries and it is often a factor limiting raising chickens and turkeys $[2,3,13]$. Heavy infestations of lice, mites, fleas, flies, and other biting insects have also been responsible for causing illness and even death of wild birds, especially among nestlings [14]. Conditions caused by these insects range from feather loss and skin damage from mange, to myiasis or 
infestation with fly maggots, and anemia.A good knowledge of the ectoparasites of the wild bird species will aid in the development of possible control measures which may help in enhancing the survival of birds and compliment efforts towards public enlightenment. There is dearth of information and knowledge on the diversity of ectoparasites infesting wild birds in Nigeria. The objective of this study was tocreate baseline information on the types of ectoparasites infesting wild birds at some gallery forests along the River Benue at Makurdi.

\section{Materials and Methods}

\subsection{Study Area}

The study was conducted at two gallery forests located along the River Benue in Makurdi local government area of Benue State. The Zoological garden $\left(7^{\circ} 43^{\prime} \mathrm{N}\right.$ and $\left.8^{\circ} 33^{\prime} \mathrm{E}\right)$ has a gallery forest located at about $1 \mathrm{KM}$ away from River Benue, Makurdi, Benue State, Nigeria and Mu gallery forest $\left(7^{\circ} 42^{\prime} \mathrm{N}\right.$ and $\left.8^{\circ} 39^{\prime} \mathrm{E}\right)$ located at about $4 \mathrm{Km}$ away from the River Benue,Benue State. The Mu gallery forest derives its name from a tributary of the River Benue located at the border between Makurdi and Gwer local governments of Benue State. The State belongs to the Koppen's Aw climate group [15]. It experiences two distinct weather conditions, dry season which starts from October to March and wet season which starts from April to September. It has a mean temperature of $28^{\circ} \mathrm{C}$, which sometimes rises to about $37^{\circ} \mathrm{C}$ especially within Makurdi the state capital. Rainfall ranges between 12,000-20,000mm.

\subsection{Sample Collection}

The trapping of birds was done from the months of September 2015 to August 2016 using mist nets. Four nets were set 100 metres apart at each study site and left in the field; nets were opened four times a week interchangeably in the mornings from 0530 to 1000 hours. Nets were inspected at 30 minutes intervals, trapped birds were immediately removed and bagged to reduce the escape of fragile parasites. Bagged birds were moved to a rest spot where each bird was first visually examined, after which they were dusted with an insecticidal powder (10\% pyrethrum) and held over a coloured cardboard paper followed by systematic thorough ruffling of the feathers in order to dislodge parasites after which contents were transferred into a labeled vial containing $70 \%$ ethyl alcohol and stored in the laboratory for microscopic examination [6]. The trapped wild birds were identified using Field guides [16], while the ectoparasites were mounted on slides and examined using a light microscope with the $4 \mathrm{X}$ and $10 \mathrm{X}$ objective lenses. They were sorted and identified to genera based on their morphology according to relevant literatures and published taxonomic key references [4, 17-19].

\subsection{Data Analysis}

Ectoparasites dynamics such as mean intensity and prevalence were calculated using relevant equations $[20,21]$.

$$
\begin{gathered}
\text { Mean Intensity }=\frac{\text { Total Number of conspecific Ectoparasites }}{\text { Number of Infected Birds }} \\
\text { Percentage Prevalence of Ectoparasite }=\frac{\text { Total Number of birds infected by an individual parasite }}{\text { Total number of birds examined }} \times 100
\end{gathered}
$$

\section{Results and Discussion}

A total of 254 wild birds were captured distributed in 33 families. Mean number of birds trapped between the months was not significant $\left(\mathrm{F}_{(11,141)}=0.629, \mathrm{P}>0.05\right)$. Birds diversity between sites was also not significant $\left(\mathrm{F}_{(1,106)}=2.131\right.$, $\mathrm{P}>0.05)$. Overall, $\mathrm{Mu}$ Forest had a total bird population of one hundred and twenty two (48.03\%), with the Red-eyed Dove (Figure 1) rating highest with a population of twelve (12), while the Zoological Garden had a total population of one hundred and thirty two $(51.97 \%)$ with the Blue-breasted Kingfisher (Figure 2) rating highest having a population of nine (9). This is an implication that birds species distribution is even between sites and all year round.

Out of the 254 wild birds, $174(68.5 \%)$ were infested with 1,294 ectoparasites (1,208 lice, 25ticks, 50 mites and 11 flies).Lice were predominant $(93.4 \%)$ than all other ectoparasites with the genus Columbicola (Figure 3) being the most prevalent species $(20.8 \%)$ while the fly Pseudolynchiasp. (Figure 4) was the lowest (1.18\%). The genus Strigiphilus(Figure 5) had the highest mean intensity of 6.88 followed by Genus Coloceras (Figure 6).

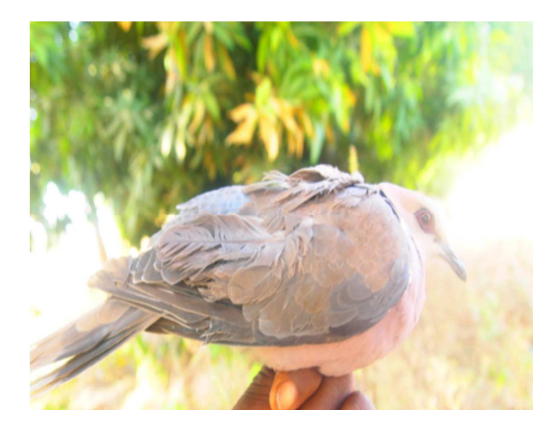

Figure 1. Red-Eyed Dove Streptopelia semitorquata.

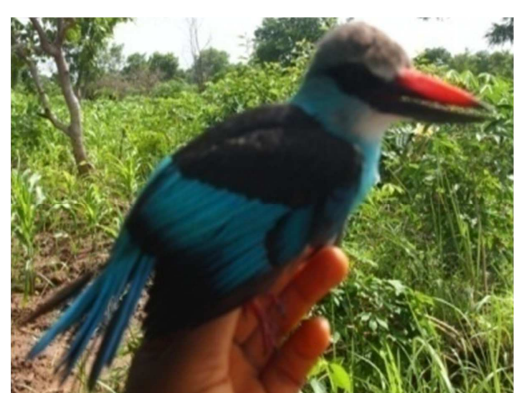

Figure 2. Blue-breasted Kingfisher Halcyon malimbica. 
Ectoparasiticinfestation varied significantlybetween months $\left(\mathrm{F}_{(11,253)}=2.620, \mathrm{P}<0.05\right)$ and between bird species $\left(\mathrm{F}_{(58,253)}=2.353, \mathrm{P}<0.05\right)$, with the months of May and June showing higher infestations and at the Mu Forest (Figure7) this may be explained by the presence of the Northern

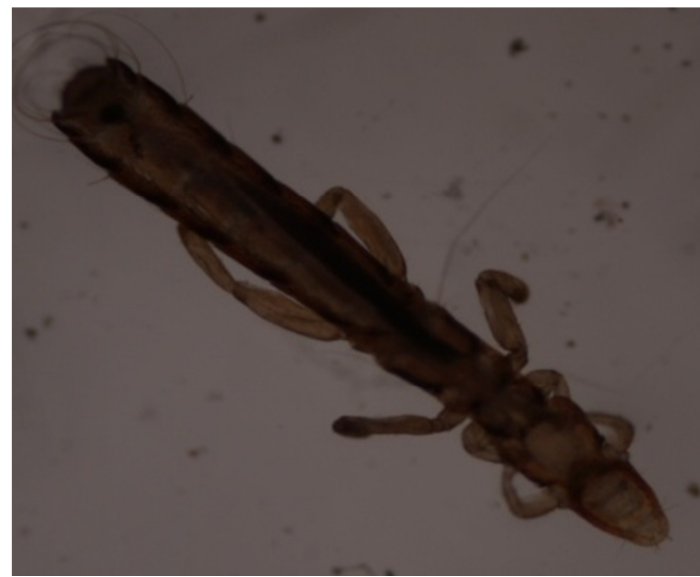

Figure 3. Columbicola sp.

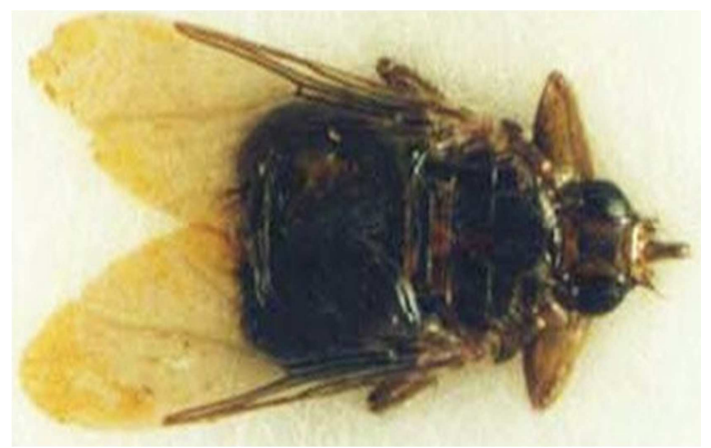

Figure 4. Pseudolynchia sp.

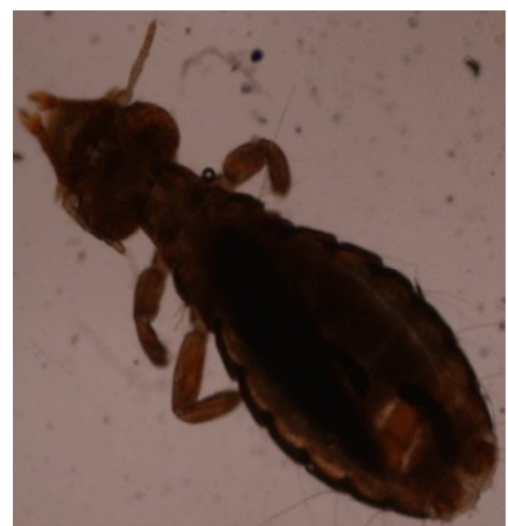

Figure 5. Strigiphilus sp.

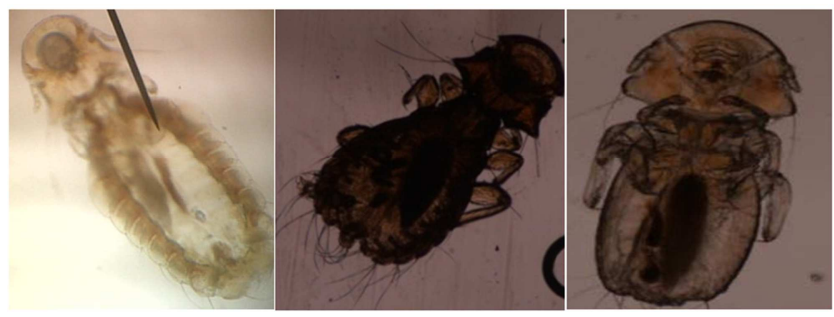

Figure 6. Coloceras spp.

White faced Owl Ptilopsisleucotis (Figure 8), which only one bird had as much as 59 ectoparasites, this completely changed infestation rate and mean intensity between species. This type of aggregate distribution was earlier explained by Claython and Waltherin their work on quantification of arthropod parasites of birds as being characteristic of ectoparasites especially lice species [6]. However, this difference was not significant when analysed according to seasons $\left(\mathrm{F}_{(2,253)}=1.975, \mathrm{P}>0.05\right)$ and sites $\left(\mathrm{F}_{(1,253)}=0.096\right.$, $\mathrm{P}>0.05)$.
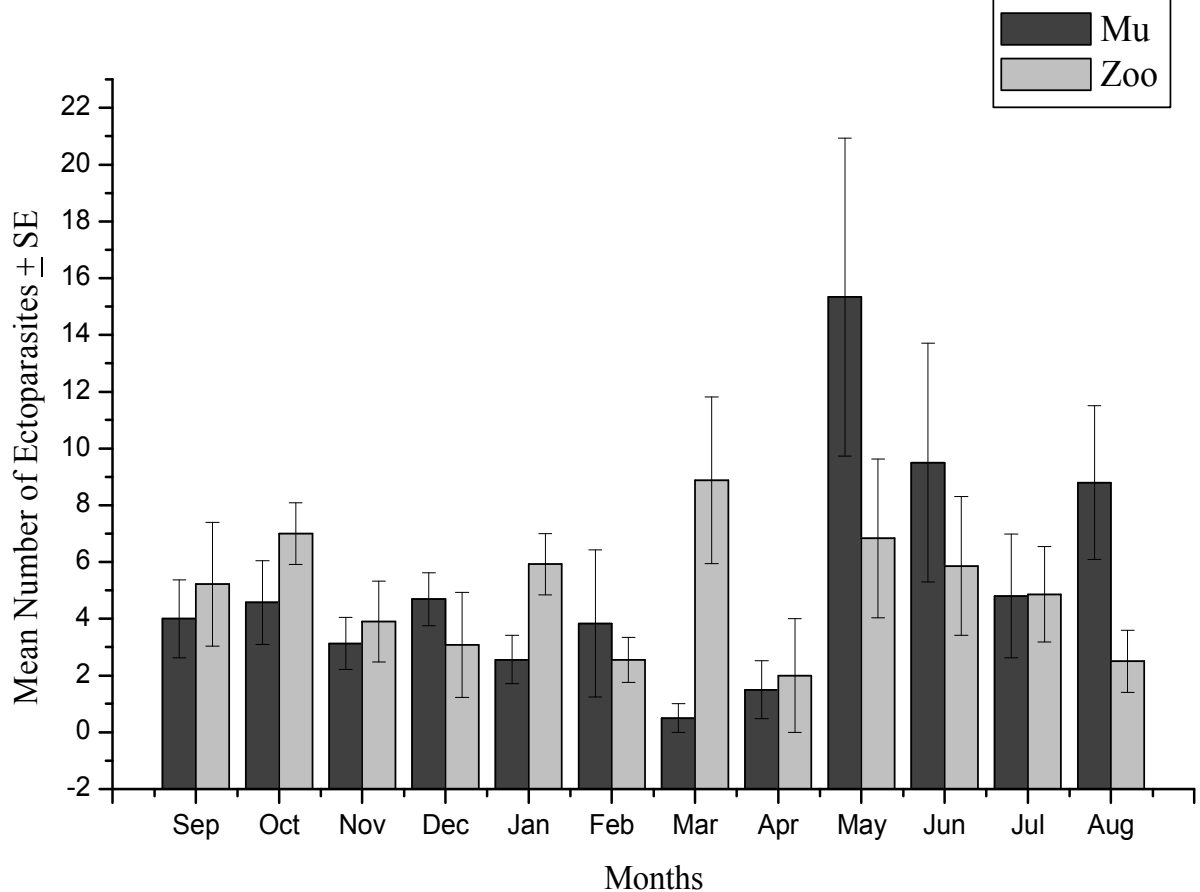

Figure 7. Mean ectoparasitic infestation at both sites across months. 


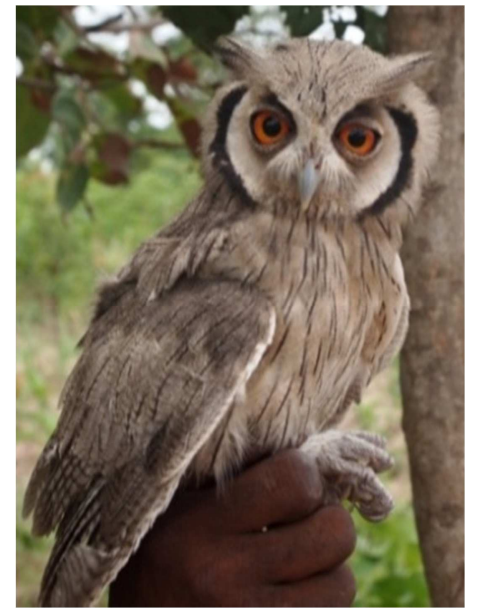

Figure 8. Northern White-faced Owl Ptilopsis leucotis.

This means that even though the ectoparasites exhibit an aggregate type of distribution, they are wide spread all year round.

Hence, the overall prevalence of ectoparasites at the gallery forests along River Benue at Makurdi is high compared to that found on wild birds in Czech Republic,
Philippines, Turkey and other parts of Nigeria[22-25]. Ectoparasites species distributed in 25 genera were recovered from this study, thisishigh compared to other studies carried out in Nigeria [26, 27], however it is worthy to note that not much work has been carried out on ectoparasites of wild birds in Nigeria, and studiesconducted so far tend to focus on specific species and on helminth parasites [28].

The lice genusColumbicolawas more prevalent (Table 1), this genus specificallyhas also been found to infest domestic birds such as pigeons and poultry [22,29]. This may be because it has developed a morphology that makes it easyto adapt to almost any part of a birds body and easily escape preening by running through the feathers hence, its ability to thrive easily [18]. Although habitat specialization was not directly investigated in this study, however, it can be assumed that Columbicola was more prevalent due to its morphological adaptation strategies against host defenses. This was explained by other researchers who investigated microhabitat specialization of ectoparasites species [4, 18].The generaStrigiphilus and Colocerasshowed a higher mean intensity of 8.40 and 6.88 respectively (Table 1).

Table 1. Prevalence and Mean intensity of Ectoparasites on wild bird species.

\begin{tabular}{lllll}
\hline Ectoparasite(Genus) & No. of birdsinfested & Prevalence & No. ofEctoparasites & Mean Intensity \\
\hline Argas & 8 & 3.15 & 25 & 3.13 \\
Dermanyssus & 7 & 2.76 & 20 & 2.86 \\
Stelkovicarus & 6 & 2.36 & 30 & 5.00 \\
Pseudolynchia & 3 & 1.18 & 11 & 3.67 \\
Coloceras & 17 & 12.69 & 117 & 5.88 \\
Brueelia & 32 & 5.51 & 169 & 3.28 \\
Gonoides & 14 & 6.30 & 43 & 4.06 \\
Chapinia & 16 & 4.72 & 65 & 3.17 \\
Philopterus & 12 & 5.11 & 38 & 2.92 \\
Alcedoecus & 13 & 12.20 & 38 & 4.13 \\
Sturnidoecus & 31 & 0.87 & 128 & 4.17 \\
Columbicola & 53 & 6.69 & 221 & 3.50 \\
Horhostiella & 2 & 3.93 & 7 & 4.41 \\
Myrsidea & 17 & 1.97 & 45 & 4.20 \\
Degeeriella & 10 & 1.97 & 11 & 2.20 \\
Hopkinsiella & 5 & 3.54 & 42 & 8.40 \\
Strigiphilus & 5 & 3.14 & 24 & 3.67 \\
Falcolipterus & 9 & 3.54 & 33 & 3.00 \\
Psittamenopon & 8 & 35 & 3.67 \\
Philopterus & 9 & 2.36 & 5.83 \\
Splendoroffula & 6 & & & \\
\hline
\end{tabular}

These genera were also recovered only from the Northern White faced owl and Dove species respectively. This typeof host-specificity is characteristic for lice species owing to the fact that lice species may have ability to develop a strategy for avoiding inter-specific competition [30, 31]. Reeves also noticed this type of host specificity in lice species infesting Bats [32].

\section{Conclusion}

This study concludes that there is high prevalence of ectoparasites on wild birds at gallery forests along River
Benue at Makurdi, Benue State, Nigeria. The major ectoparasites comprises lice and mites, which have been implicated as causative agents of various diseases in other birds, with the genus Columbicolaas the most prevalent ectoparasites species of wild birds in Makurdi.These forests may also be acting as reservoir for ectoparasites transmission between domestic and wild birds.

Finally, European migrants were not trapped at any of the study sites, perhaps these sites do not act as a migratory path or wintering site for the birds, however, some intra African migrants were trapped at the sites. It will therefore be interesting to investigate the effects that these parasites have 
on birds' health and productivity and also to establish the type of diseases they transmit between birds of different species.

\section{References}

[1] Moyer, B.R andClayton, D.H. (2014). Avian Defenses AgainstEctoparasites.Department of Biology, University of Utah, Salt Lake City, UT84112, USA.

[2] Biu, A.A., Agbede, R.I.S., and Peace, P. (2007). Studies on ectoparasites of poultry in Maiduguri, Nigeria, Journal of Parasitology, 28:69-72.

[3] Al-Saffar, T.M. and Al-Mawal, E.D. (2008). Some Hematological changes in chickens infected with Ectoparasites in Mosul. Iraqi Journal of Veterinary Sciences, 22: 95-100.

[4] Clayton,D.H, Koop, J.A.H, Harbison, C.W, Moyer, B.R and Bush, S.E. (2010). How Birds Combat Ectoparasites.The Open Ornithology Journal, 3:41-71.

[5] Loye, J.E. and Carroll, S.P. (1991). Nest ectoparasite abundance and cliff swallowcolony site selection, nestling development, and departure time. In Bird-parasite interactions: Ecology, evolution and behaviour, J. E. Loye and M.Zuk (eds.). Oxford University Press, Oxford, U.K., Pp. 221-241.

[6] Clayton, D.H. and Walther, B.A. (1997). Collection and Quantification of Arthropod parasites of Birds in: Clayton, D. H. and Moore, J. (eds). Host-parasite evolution: general principles and avian models. Oxford University Press, Oxford. Pp 419-440.

[7] Moller, A.P. (1993). Ecto-parasites increase the cost of reproduction in their hosts.Journal of Animal Ecology62: 309322.

[8] Santiago-Alarcon, D., Whiteman, N.K., Parker, P.G., Ricklefs, R.E andValkiunas, G. (2008). Patterns of Parasite Abundance and Distribution in Island Populations of GalapagosEndemic Birds.Journal of Parasitology.94(3): 584-590.

[9] Sekercioglu, C.H. (2002). Impacts of birdwatching on human and avian communities.Environmental Conservation,29: 282289.

[10] Millennium Ecosystem Assessment (2003). Ecosystems and Human Well-being: AFrameworkfor Assessment.Island Press. Washington, DC.

[11] Roberson, D. (2014). Bird Families of the World. Retrieved fromcreagrus.home.montereybay.com/list.html on 20th January 2015.

[12] Alves, R.R.N, Leite, R.C.L, Souto, W.M.S, Bezerra, M.M.D and Loures-Ribeiro, A. (2013).Ethno-ornithology and Conservation of Wild Birds in the semi-arid Caatinga of northeastern Brazil.Journal of Ethnobiology and Ethnomedicine, 9:14.

[13] Nnadi, P.A. andGeorge, S.O. (2010). A Cross-Sectional Survey on Parasites of Chickens in Selected Villages in the Sub humid Zones of South-Eastern Nigeria. Journal of Parasitology Research Vol. 2010, Article ID 141824, 6 pages.

[14] Carleton, R.E (2008). Ectoparasites affect hemoglobin and percentages of immature erythrocytes but not hematocrit in nestling Eastern Bluebirds. The Wilson journal of Ornithology, 120: $565-568$

[15] Chen, D. andChen, H.W. (2013).Using the Köppen classification to quantify climate variation and change: An example for 1901-2010.Environmental Development, 6, 6979.

[16] Borrow, N. andDemey, R. (2013). Birds of Western Africa, Christopher Helm, an imprint of Bloomsbury Publishing 50 BedfordSquare, London. 511pp

[17] Inci, A., Dik, B., Kibar, M., Yildirim, A. and Duzlu, O. (2010). Chewing Lice (Phtheraptera) Species on Wild Birds in Coppadocia Region, Turkey.TurkiyeParasitol. Derg, 34:174-178.

[18] Johnson, K. P., Shreve, S.M. andSmith, V.S. (2012). Repeated Adaptive Divergence of Microhabitat Specialization in avian feather lice.BMC Biology, 10:52.

[19] Dik, B. and Halajiam, A. (2013).Chewing Lice (Phtheraptera) of Several Species of Wild Birds in Iran, With New Records.Journal of Arthropod-Borne Diseases.7(1): 83-89.

[20] Stiling, P. D. (1996). Ecology: Theories and Applications. Prentice Hall International,Inc, USA. pp 275-301.

[21] Rozsa, L., Reiczigel, J. and Majoros, G. (2000). Quantifying parasites in samples of hosts.Journal of Parasitology, 86: 228-232.

[22] Sychra, O., Literak, I., Podzemny, P., Harmat, P.and Hrabak, R.(2011). Insect Ectoparasites onWild Birds in Czech Republic During the Pre-Breeding Period. Parasite.18:13-19.

[23] Tanasak, C., Charoonluk, J., Ruangrat, B., Kacha, C., Pavince, C., Sarin, S., Surachit, W., Kanokporn, T., Kridsada, C. andParntep, P. (2010). Ectoparasitic Fauna of Birds, and Volantand Non-Volant Small Mammals Captured at Srinakasin Dam, Kanchanabur, Thailand. Southeast Asian Journal of Tropical Medical Public Health.41(3):526-535.

[24] Su, G.I.S., Amil, C.J.A., Juan, J.A.P.S., Su, L.L.S., Maguad, G.S., Salinas, R.A.F., Raggragio, E.M., Santiago,A.T.S.A. andRamos, G.B. (2013). Ectoparasitic Survey of Quarantined Animals in a Wildlife Rescue Center in Quezon City, Philippines.World Journal of Agricultural Research,1(3): 4447.

[25] Adang, L.K., Oniye, S.J., Ezealor, A.U., Abdu, P.A., Ajanusi, J.O. andYoriyo, K.P. (2008).(Ectoparasites of the Laughing Dove Streptopeliasenegalensis(Linnaeus, 1766)(Aves: Columbidae) in Zaria, Nigeria. Lundiana,9:67-71.

[26] Adang, K.L., Oniye, S.J., Ezealor, A. U., Abdu, P.A., Ajanusi, O.J., andYoriyo, K.P. (2009). Ectoparasites and GastroIntestinal Helminths of Black-Billed Wood Dove (Turturabyssinicus) and Vinaceous Dove (Streptopeliavinacea) Hartlaub and Finsch 1870 in Zaria, Nigeria. The pacific Journal of Science and Technology, 10:850-856

[27] Edosomwan, E.U. and Amadasun, E. (2008). Ectoparasites of some birds species in Ogbazoo in Benin City, Nigeria. Bioscience Research Communications, 20: 231-235.

[28] Umar, A.Y. and Shuaib, G.A.(2017). Prevalence of helminth parasites of domestic pigeons (Columba livia) in Jalingo Metropolis, Taraba State.Nigerian Journal of Parasitology. 38:44-47. 
[29] Adelusi, S.M., Vajime, C.G., Omudu, E.A., Okpotu, R.O. and Onazi, F.O. (2014). Avian Parasitism in Makurdi, Nigeria: Do Wild Birds Serve as Reservoir for Domestic Birds? Nigerian Journal of Pure and Applied Sciences. 6:11-15.

[30] Smith, V.S. (2001). Avian louse phylogeny (Phthiraptera: Ischnocera):a cladistic study based on morphology. Zoological Journal of the LinneanSociety, London,132: 81-144.
[31] Girisgin, O.A., Dik, B. and Girisgin, O. (2013). Chewing Lice (Phtheraptera) Species of Wild Birds in Northwestern Turkey with New Host Record.International Journal of Parasitology: Parasites and Wildlife.Volume 217-221.

[32] Reeves, W.K., Beck, J., Orlova, M.V., Daly,J.L.,Pippin, K., Revan,F. and Loftis, A.D. (2016). Ecology of Bats, Their Ectoparasites and Associated Pathogens on Saint Kitts Island. Journal of Medical Entomology, 53(5): 1218-1225. 